\title{
The Berardenga Antependium and the Passio Ymaginis Office
}

\author{
Michele Bacci \\ Journal of the Warburg and Courtauld Institutes, Vol. 61. (1998), pp. 1-16.
}

Stable URL:

http://links.jstor.org/sici?sici=0075-4390\%281998\%2961\%3C1\%3ATBAATP\%3E2.0.CO\%3B2-8

Journal of the Warburg and Courtauld Institutes is currently published by The Warburg Institute.

Your use of the JSTOR archive indicates your acceptance of JSTOR's Terms and Conditions of Use, available at

http://www.jstor.org/about/terms.html. JSTOR's Terms and Conditions of Use provides, in part, that unless you have obtained prior permission, you may not download an entire issue of a journal or multiple copies of articles, and you may use content in the JSTOR archive only for your personal, non-commercial use.

Please contact the publisher regarding any further use of this work. Publisher contact information may be obtained at http://www.jstor.org/journals/warburg.html.

Each copy of any part of a JSTOR transmission must contain the same copyright notice that appears on the screen or printed page of such transmission.

The JSTOR Archive is a trusted digital repository providing for long-term preservation and access to leading academic journals and scholarly literature from around the world. The Archive is supported by libraries, scholarly societies, publishers, and foundations. It is an initiative of JSTOR, a not-for-profit organization with a mission to help the scholarly community take advantage of advances in technology. For more information regarding JSTOR, please contact support@jstor.org. 


\title{
THE BERARDENGA ANTEPENDIUM AND THE PASSIO YMAGINIS OFFICE
}

\author{
Michele Bacci
}

for Professor Enrico Castelnuovo for his 70th birthday

A $\mathrm{n}$ ancient panel, in the National Gallery in Siena, is often regarded as the earliest painted antependium in Italian art, as revealed by an inscription bearing the date of its execution in the upper border, which reads: " $\rightarrow$ an $[n] o$ $\mathrm{d}$ [omi] ni millesimo cc xv mense novembris hec tabula facta est' ('In the year 1215 in the month of November this panel was made') (Fig. 1). Embellished with pastiglia decorations which simulate precious metalwork, the painting, currently attributed to the hand of the so-called 'Tressa Master', displays in its central zone a representation of Christ in the mandorla as the 'Majestas Domini'. ' Of the six lateral scenes, two on the right side have been recognised as illustrations of the Invention of the Holy Cross in Jerusalem by St Helena, mother of the Emperor Constantine. The upper scene (Fig. 2) shows Helena interrogating the Jews about the place where their ancestors buried the wood on which Jesus had been crucified. The middle one (Fig. 3) shows a second episode from the legend: after recovering the three crosses (those of Christ and the two thieves), the Empress gives orders to test them out on a dead woman's corpse, and the cross which effects her resurrection is recognised as that of the Saviour.'2

The third scene has evidently no direct relation to the Discovery cycle, as indicated by the presence in it of a mitred figure. The scenes on the left side are also puzzling. An inscription within the middle one, referring to the Passion of Christ, has favoured its misinterpretation as an illustration of the Crucifixion. Adolfo Venturi, in 1907, sought to interpret these three scenes as representations of a legend recounting the miracle of a bleeding crucifix mocked and struck by the Jews of Berytos (Beirut). Venturi found a mention of this story in Jacobus de Voragine's Golden Legend, which, however, was written long after the execution of the panel (in 1215), since its author was born in $1228 .{ }^{+}$Giacomo de Nicola, writing in 1912, was therefore evidently right in rejecting this author as the source of the three scenes in the antependium, and the question was taken no further. In any case, although abbreviated, Jacobus's version relied on a much older story, rooted in ancient traditions of the Christian East. The present essay is devoted to the discussion of this story and its meaning in medieval hagiographical literature and liturgical practice.

\footnotetext{
* I wish to express my gratitude to $\mathrm{Mr}$ Robert Learmonth (Pisa, Scuola Normale Superiore), and to the Editors and Readers of this Journal, for their help in correcting the present text. My thanks are also due to my friends, teachers, and colleagues of the Scuola Normale Superiore, and to Barbara, for her patient and continuous encouragement.

1 A bibliographical survey on the panel can be found in P. Torriti, La Pinacoteca di Siena. I dipinti, Genoa 1990, p. 10. On its pastiglia decorations see M. S. Frinta, 'Raised Gilded Adornment of the Cypriot Icons, and the
}

Occurrence of the Technique in the West', Gesta, xx, 1981, pp. 333-47 (334).

2 On the iconography of the Invention cycle see A.

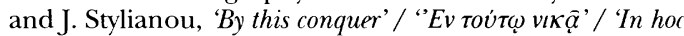
vinces, Nicosia 1971.

3 A. Venturi, Storia dell'arte italiana, 11 vols, Milan 1901-40, v, pp. 80-2.

+ Jacobus de Voragine, Legenda aurea, cxxxvii; ed. T. Graesse, Dresden 1890, pp. 608-9.

5 G. De Nicola, 'Arte inedita in Siena e nel suo territorio', Vita d'arte, x, 1912, pp. 1-16 (3). 




Fig. 1-Master of Tressa, painted antependium, 1215. Siena, Pinacoteca Nazionale

Recent scholarship has proposed that the antependium was originally designed for use in the liturgy of Siena Cathedral in the earlier thirteenth century. On the basis of a passage in the local Ordo officiorum, compiled by a canon named Odericus in 1215, it has been supposed that a 'tabula' containing relics of the Holy Cross, which was exposed on the high altar on 14 September (the feast of the Exaltation of the Cross), may be identified with the antependium. As Kees van der Ploeg has observed, the lateral scenes of the panel, referring to the Legend of the True Cross, would have been well designed to stimulate 'veneration for the Lord's suffering body by means of devotion to the Holy Cross... ${ }^{6}$ But it is clear that, if we agree with this supposition, we have to regard our antependium as a reliquary for a fragment of the True Cross. However, no details in the panel and nothing in its structure corroborate such a view. The Exaltation of the Cross was a minor feast in Siena, since the commemoration of a local patron saint, Crescentius, was recorded on the same day; on Good Friday, a crux containing a relic of the Cross was exhibited on the high altar and venerated by the clergy and the people. Can we suppose that such a cross and the tabula of the Exaltation day were identical?

The interpretation of the antependium as an object involved in Sienese liturgical practice has constituted the main argument for rejecting an original location in the abbey church of San Salvatore della Berardenga, near Monastero d'Ombrone in the diocese of Arezzo, where the panel was preserved before the final suppression of the monastery in 1820. In the opinion of Henk van Os, the original setting of the antependium in the abbey of Berardenga may be explained as a consequence of the renovation promoted by the commendatory abbot Alessandro Zondadari, Archbishop of Siena, about 1689. Zondadari, van Os suggests, solicited the transfer of an old panel originally in Siena. ${ }^{7} \mathrm{He}$ infers that the high artistic quality of the antependium can be better understood by supposing an original destination in a more prestigious

${ }^{6}$ K. van der Ploeg, Art, Architecture and Liturgy. Siena Cathedral in the Middle Ages, Groningen 1993, pp. 75-6.
7 H. van Os, Sienese Altarpieces 1215-1460, 2 vols, Groningen 1984-90, i, pp. 15-17, 100. 


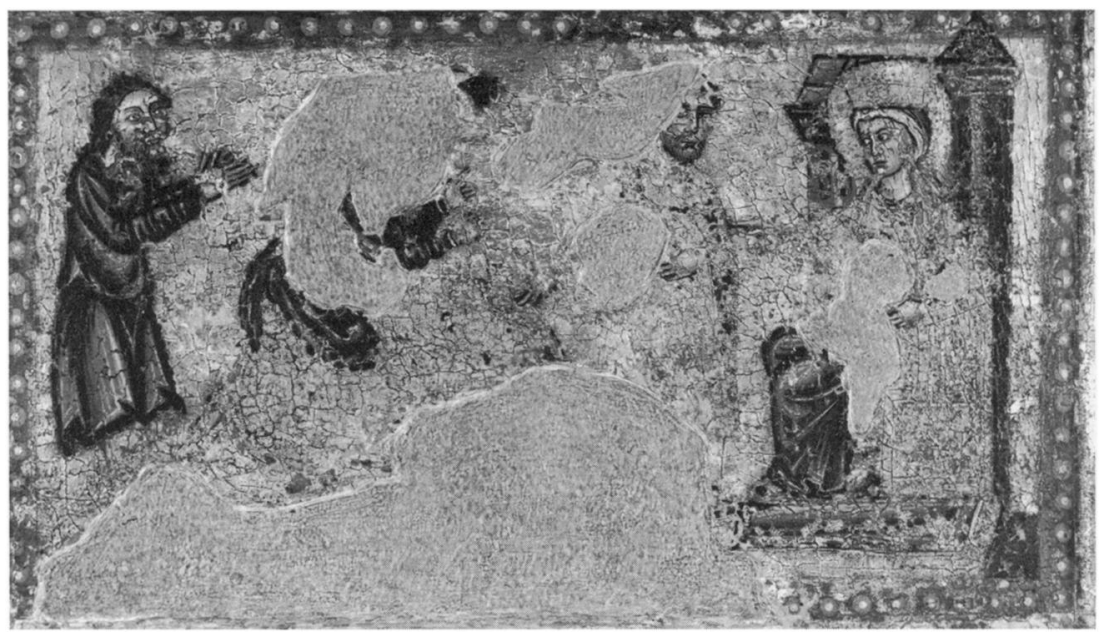

Fig. 2-The Interrogation of the Jews by St Helena

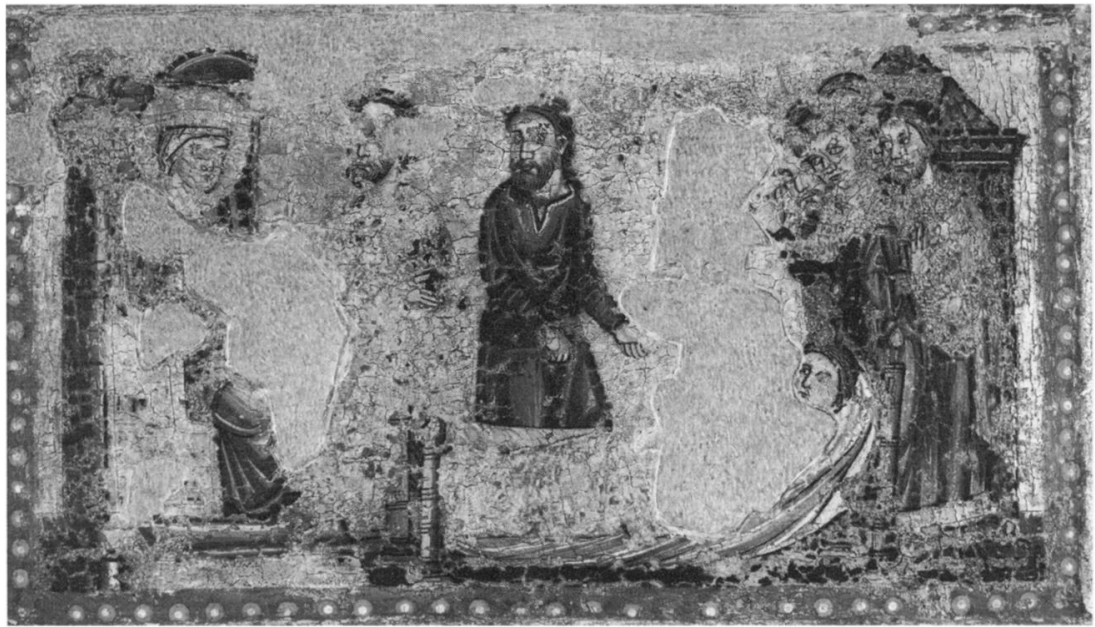

Fig. 3-The Testing of the Crosses by St Helena

church, such as Siena Cathedral. However, this hypothesis contrasts with the important role played by the abbey of Berardenga in the central Middle Ages. Founded in 867 by Count Winigis, the Carolingian Lord of Siena and its territory, it grew in the following centuries under the protection of the powerful Berardenghi family. The area subject to the abbey was wide, ranging from the whole territory of Castelnuovo Berardenga to its extensive possessions in Asciano, Bucine, Gaiole and Rapolano. Moreover, a hospital for pilgrims was attached to the monastery in the twelfth century. ${ }^{8}$ In 1003 the abbey church was solemnly re-dedicated to the Saviour and St Alexander, both remembered as patrons since 881. Its feast, which fell on 9 November, now corresponds to the Dedication of the Lateran Basilica in Rome,

8 P. Cammarosano, La famiglia dei Berardenghi. Contributo alla storia della società senese nei secoli XI-XIII, Spoleto 1974, pp. 64-84, 93-103, 273-331. 
but in ancient times commemorated the Saviour's renewed Passion in his Beirut image.

In a session of the anti-iconoclastic council of Nicæa in 787, Bishop Peter of Nicomedia read publicly a sermon ascribed to St Athanasius, relating the story of a miracle that occurred in Beirut. ${ }^{9}$ This legend, probably born of antisemitic propaganda among Eastern Christians (variants are known in Jacobite Syrian and Coptic texts) ${ }_{10}^{10}$ was employed and augmented by Iconophiles as an argument against their enemies, since it was validated by an authoritative Father of the Church. The sermon was introduced to the West through the Latin version of the Nicæan acts, compiled by Anastasius the Librarian around 872, where the events were expounded in the same order, apart from an addition ascribing a part in the story to St Nicodemus."

The sermon ascribed to Athanasius in Anastasius's version is clearly reflected in the iconography of the Siena antependium. After a prologue describing the geographical location of Beirut, the story tells of a pious Christian who used to pray in his bedroom to a portrait of Christ which "was assuredly venerable, because it reproduced the full figure of Christ the Lord'. ${ }^{12}$ This man's house, located near to the local synagogue, was very small, so he decided to search for more comfortable accommodation in another part of town. When he moved to his new address, he left his icon in the old house and the new owner, a Jew, did not realise that an image of Christ was hung in the bedroom. The sermon goes on:

One day, as this man invited some of his gentile fellows to dinner, it happened that one of his guests glanced at the image of Christ our Lord and so addressed his host as follows: 'How have you the effrontery, as a Jew, to have such an image in your own house?'... Anyway, the host, who desired to defend himself, declared with innocence that he had not noticed it before; then the guest became silent. ${ }^{13}$

This passage is illustrated in the upper scene on the left side of the Siena antependium (Fig. 4). The Jews are at table and are having their meal, when a bearded man notices an image of Christ-represented as an early thirteenth-century Italian painted cross-and points to it, calling his host to account. The owner, seated beside him, exculpates himself, as shown by the gesture of his hand. The middle scene (Fig. 5) depicts the next episode of the legend. As the sermon tells us, the treacherous guest did not believe his host and, after dinner, charged him with blasphemy in front of the priests and the elders. The Sanhedrin resolved to seize the image. On bursting into the house, some of the Jews cried wildly: 'As our fathers once mocked at him, so let us do now!' Immediately everyone started spitting at the icon. Then they said: 'We know that our fathers nailed his hands and feet: what can prevent us from attempting

9 The Greek text is edited by G. D. Mansi, Sacrorum
conciliorum nova et amplissima collectio, 31 vols, Florence
and Venice 1759-98, xiii, cols 24-32; and J.-P. Migne,
Patrologice cursus completus. Series graca (hereafter PG),
Paris $1857-66$, xxviii, cols 797-812.
10 See the Syriac story of an outraged sacred image in
Tiberias, ed. and tr. E. A. Wallis Budge, The History of
the Blessed Virgin Mary and the History of the Likeness of
Christ Which the Jews of Tiberias Made to Mock At, London
1899, ii, pp. 171-246. For Coptic variants see B. Pirone,
'Sangue e icone nella tradizione della Chiesa egiziana',
Sangue e antropologia nel Medioevo (Atti della VII setti-
mana, Rome 1991), ed. F. Vattioni, 2 vols, Rome 1993, i,
pp. $453-89$.
11 The full text is edited in Mansi (as in n. 9), xiii,
cols 580-5. On its history and importance as a topos in medieval Latin literature see J.-M. Sansterre, 'L'image blessée, l'image souffrante: quelques récits de miracles entre Orient et Occident ( $\mathrm{VI}^{\mathrm{e}}-\mathrm{XII}^{\mathrm{e}}$ siècle)', Les images dans les sociétés médiévales: pour une histoire comparée (Actes du Colloque international, Rome 1998), forthcoming.

12 Ibid., col. 580: 'erat hæc sane veneranda, quod integram Christi Domini proportionem exprimeret'.

13 Ibid., col. 581: 'Quodam autem die hic cum gentilium suorum quosdam in prandium invitasset, contigit, ut quidam convivarum sublatis oculis imaginem Christi Domini nostri inspiceret: moxque conversus ad convivatorem: tu (inquit) Judæus cum sis, qua fronte tandem audes hujuscemodi imaginem domi tuæ habere? ... Convivator autem seipsum purgare studens affirmabat etiam sancte, se hujuscemodi imaginem hactenus non vidisse: atque ita qui invitatus erat, tacuit'. 


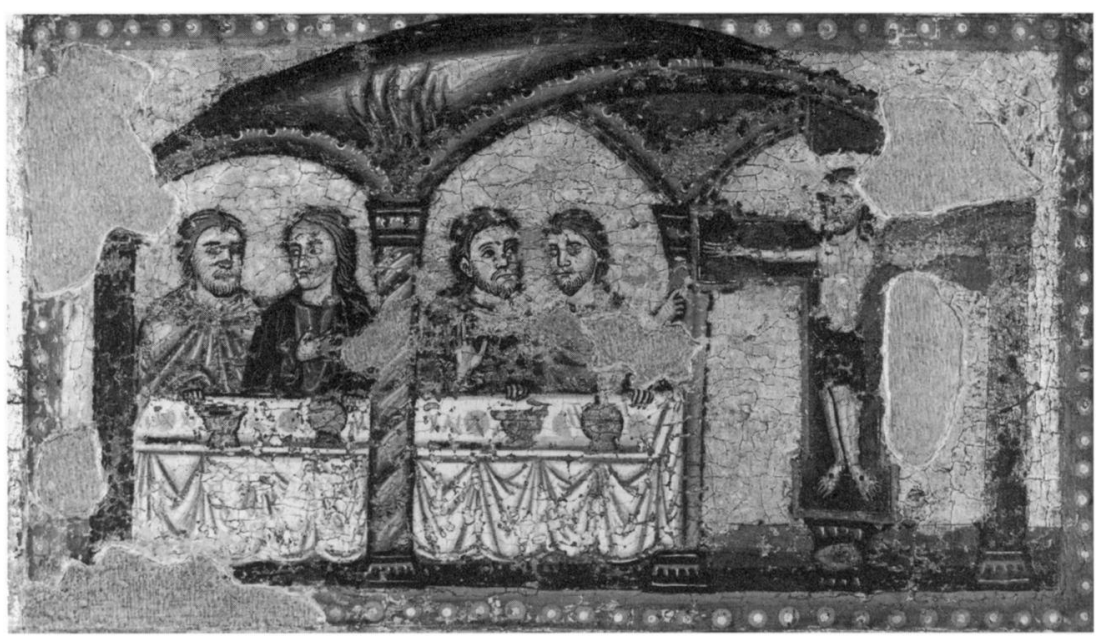

Fig. 4-The Beirut Jews' symposium

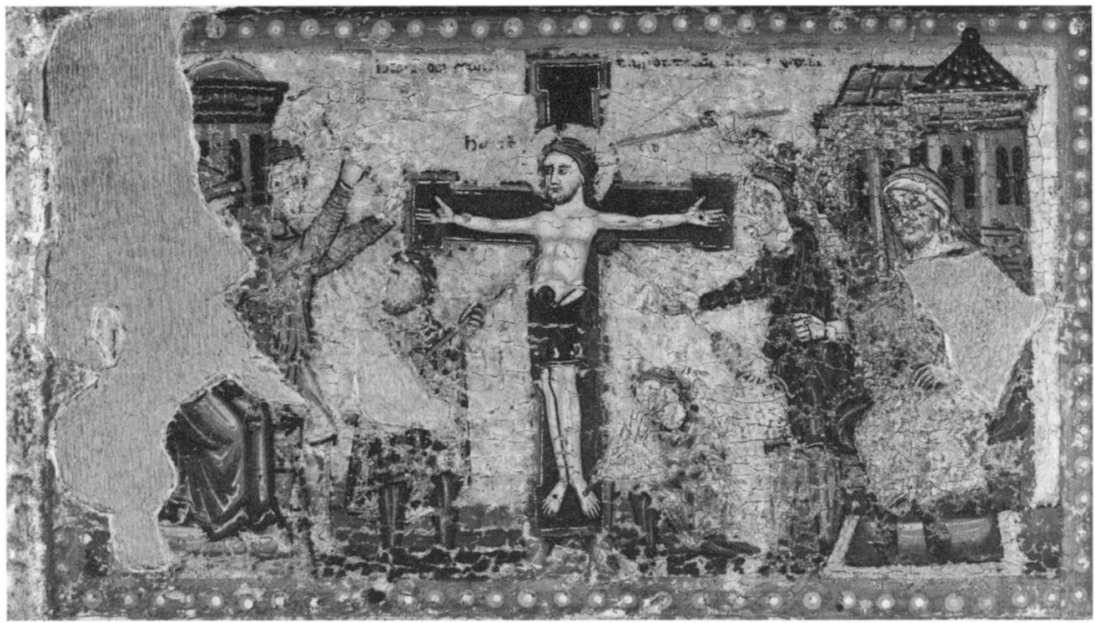

Fig. 5-The Beirut Crucifix outraged by the Jews

the same?' So they hammered nails into the icon and, again, voices cried: 'We know that they quenched his thirst with a sponge soaked with vinegar and gall: let us do the same.' When this had been done, further voices suggested whipping the icon. Some of them urged: 'It is common knowledge that they pierced his side with a lance. Let's leave nothing out: let's add that too!' ${ }^{14}$ As we can see, every torment inflicted on the

14 Ibid., col. 581: 'Cum autem ad eum locum venissent seniores et principes sacerdotum cum ipso simul delatore, irruunt in domum, et confestim imaginem Salvatoris Domini nostri contemplati, furore pleni, Judæum quidem extra synagogam ejiciunt, imaginem vero detrahunt, dicentes: Quemadmodum patres nostri illuserunt illi, ita et nos faciamus. Tunc omnes coperunt expuere in faciem sanctæ imaginis Christi, colaphisque hinc illinc faciem cædentes dicebant: Quæcumque designarunt patres nostri in illum, ea et nos quoque faciamus in illius imaginem. Deinde inquiunt: Audivimus quod illuserunt ei patres nostri, faciamus idem hoc et nos quoque: Mox talia convicia evomuerunt in Jesu Christi imaginem, quæ nemo sanæ mentis excogitare posset. Addunt deinde: Audivimus, patres nostros pedes manusque illius clavis fixisse: quid obest, quo minus et nos idem tentemus? confestim autem imaginis Domini pedes manusque clavis ferreis foraverunt. Deinde insano ore clamant: Audivimus quod et aceto et felle imbuta spongia illum potaverunt: faciamus et nos similiter: 
image is represented in our scene: in the presence of some Sanhedrin members, the crucifix is being nailed by a kneeling figure on the right, while another lifts the sponge and a third man (mostly obliterated) strikes Christ's head with a reed. On the left side, a bearded man stabs his side with a lance. The inscriptions referring to Christ's Passion are now mostly obliterated, but, according to Cesare Brandi's transcriptions, they read: 'This is the King of the Jews <...' ('Hoc est Rex Iudeorum $<\ldots>$ '), and 'Here is God's venerable Passion <...>' ('Hic est Dei excolenda Passione $\left.<\ldots\rangle^{\prime}\right) .{ }^{15}$ Their function was clearly to stress the meaning of the miraculous episode as a repetition of Christ's Passion in His image.

The lower scene (Fig. 6) illustrates what follows in the narration. As the sermon relates, when the icon was pierced through its side, blood and water began to pour from the wound. The Jews were astonished at such a miracle and the priests decided to test the thaumaturgic power of the holy liquids. Some of them brought a bowl ( hydria) to the wound and filled it. Then they said to each other: 'Since Christian worshippers say that He was the author of many unprecedented miracles in the world, let's collect this blood and this water and take them to our synagogue, where we will gather everyone who is ill. We will sprinkle them with these liquids: if what is said about Christ is true, everybody will be immediately cured; otherwise, we'll use them as a proof against what his believers declare about Him.' So they called for a man who was affected with paralysis since birth, and, after being sprinkled with the blood and the water of Christ's icon, he was able to walk and run like a deer. Afterwards, they did the same to some blind people, and they too were healed. ${ }^{16}$ Every detail of this passage-which is absent in Jacobus de Voragine's version-is reproduced in the Sienese panel. On the left, a Sanhedrin priest, with a clear gesture, orders the collection of the miraculous liquid, a bearded man fills the hydria, and another man expresses astonishment. On the right is the prodigious recovery: under an arch symbolising the synagogue, the paralytic is shown in the foreground, while the healing of the blind takes place behind him.

In these three scenes, where the image of the crucifix plays the role of protagonist, the most noteworthy moments of the Beirut story are eloquently summarised. However, the narration goes further in Anastasius's version and speaks about the general conversion of the Beirut Jews. They told the bishop of the events and asked

acceptaque spongia aceto plena, ad os imaginis applicuerunt. Rursus ajunt: Notum nobis est, quod et calamo caput illius patres nostri percusserint. Fiat idipsum etiam a nobis pariter: sumpto igitur calamo caput Domini cædere cœeperunt. Tandem ajunt: Clarum nobis est, quod lancea latus illius pepugerunt: nihil a nobis omittatur: addamus et hoc ipsum: itaque lanceam cuidam porrigentes, jusserunt, ut latus imaginis dominicæ transfigeret'.

15 C. Brandi, La Regia Pinacoteca di Siena, Rome 1933, p. 20.

16 Mansi (as in n. 9), cols 582-3: 'Postquam enim, (ut superius dictum est) latus sanctæ imaginis illius apertum est, continuo exivit sanguis et aqua. Dixerunt autem principes sacerdotum: Afferatur vas ad locum vulneris, et videamus exitum rei. Qui illico detulerunt hydriam, et ad locum vulneris, unde sanguis et aqua decurrebant, statuerunt. Quæ absque ulla mora subito repleta est. Dixerunt autem ad invicem: Quoniam susurrant Christum colentes, quod signa et inaudita multa fecerit in mundo, quæ nemo alius agere potuit, accipiamus hunc sanguinem et aquam hanc, et deferamus ad nostram synagogam, et congregemus universos qui se male habent, et ex hoc spargamus eos: et si vera sunt, quæ de Christo dicuntur, continuo sanabuntur: sin alias, ostentui habeantur a nobis cuncta, quæ a suis sequacibus asseruntur de eo. Hæc dicentes, hydriam deferunt ad synagogam, æstimantes se Christo Jesu Domino vostro æterni regis filio maximam inferre posse injuriam. Congregaverunt igitur quoscumque repererunt languidos: et in conspectu Hebræorum introducti in synagogam, inter quos quidam provectæ ætatis erat homo, quem a nativitate sua gravissima possederat corporis molestia, quæ Græca locutione $\pi \alpha \rho \dot{\alpha} \lambda v \sigma \iota \varsigma$, Latine vero dissolutio membrorum dicitur. Hic dum primum ab eis fuisset perunctus, repente de suo grabbato [sic], quasi cervus exiliens, ad laudem Filii Dei incolumis redditus, ad propria remeavit. Deinde adducentes cæcos nonnullos, loca eorum luminum perungere studuerunt. Qui ipsi statim in Jesu Christi nomine discussa cæcitate, post multos annos lumen amissum recipere meruerunt'. 


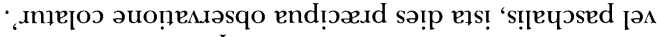

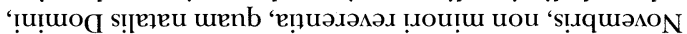
snpI olu!̣nb 'isa p! 's!suəu sn!̣sd! ว!̣ ouou 'snu!̣วpun

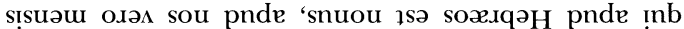

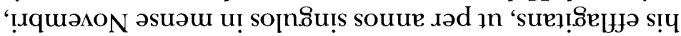

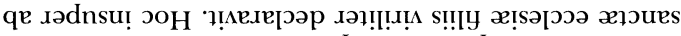

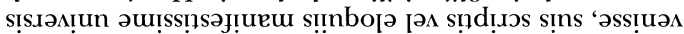

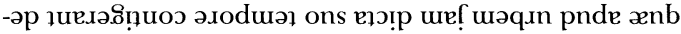

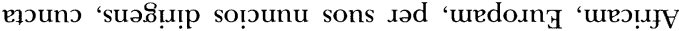

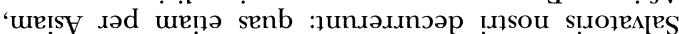

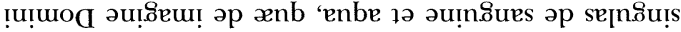

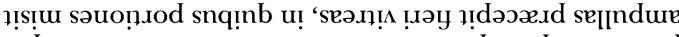

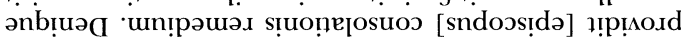

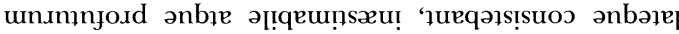

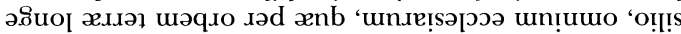

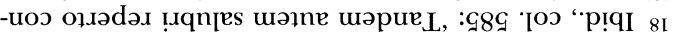
‘łun.əsdunsæ.

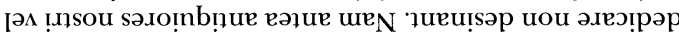
1ә әләриол !punu s!oles

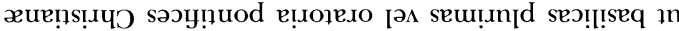

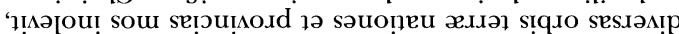
sad anbę! Jum x

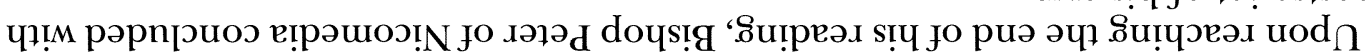

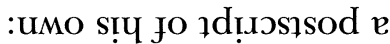

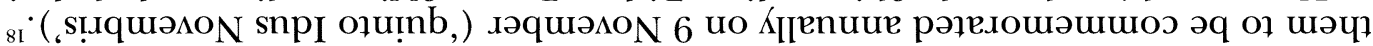

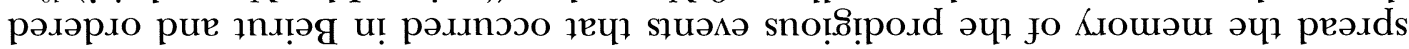

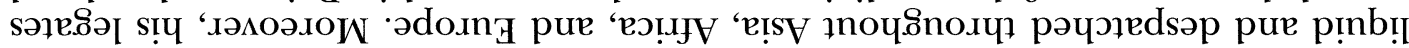

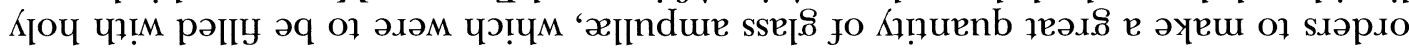

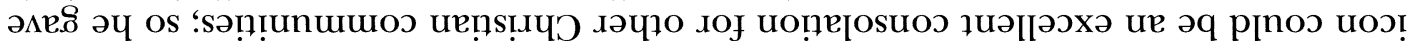

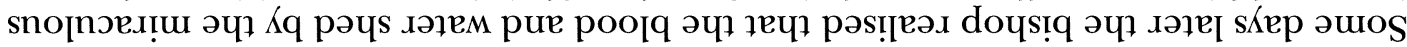

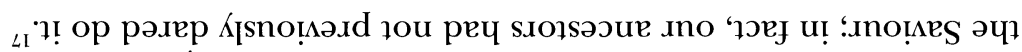

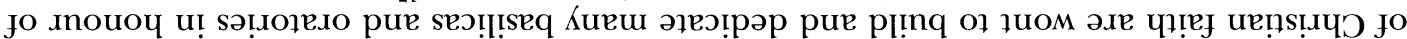

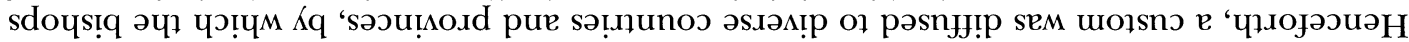

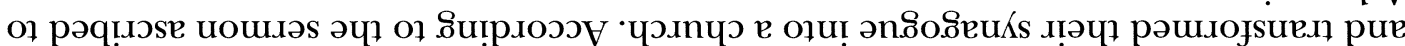

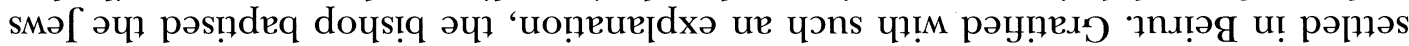
иәчl '

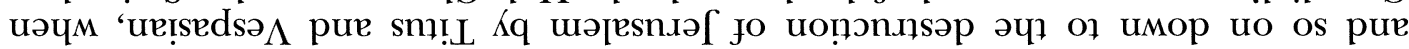

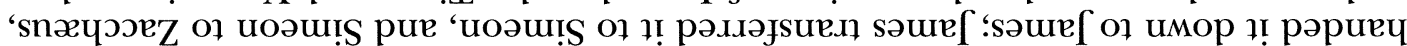

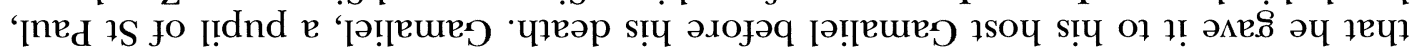

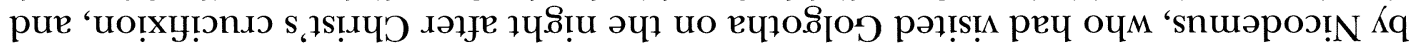

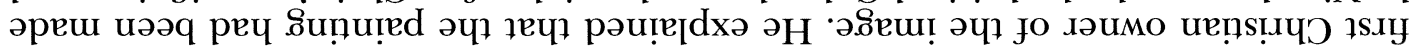

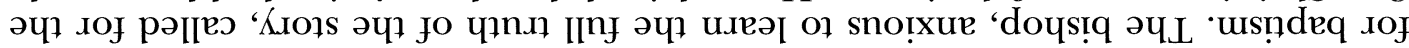

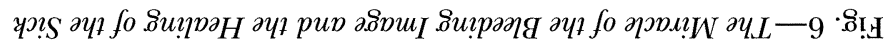

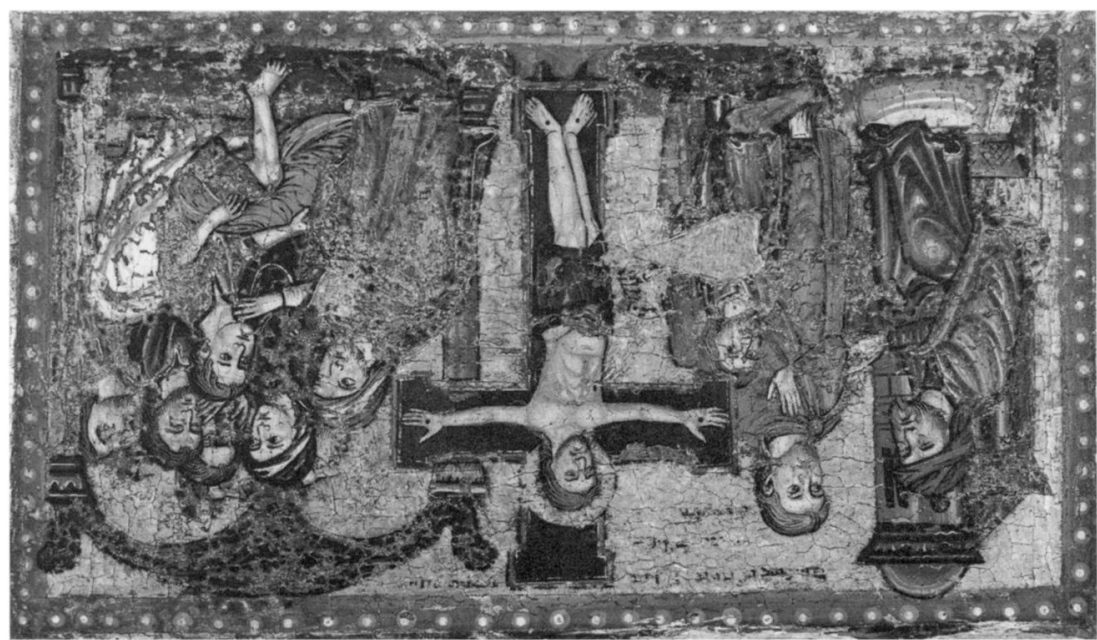


This is the true and absolutely believable story of the blood from our Lord and Saviour's side, which was shed through His holy image crucified in Syria, in the town of Beirut. This is also that blood of the Lord many say they possess. True catholics cannot believe differently from what we have written, that is, nothing of Christ's flesh and blood can be found in the world apart from that which is daily made spiritually on the altar, by the hand of priests. Aware, therefore, of this, beloved fathers and brothers, I have made haste to declare it to you for the edification of your souls and the deepening of our faith, so that you can know from this too how great are the power and goodness of our God and Lord Jesus Christ the Saviour. ${ }^{19}$

As this interpolation indicates, relics of the Beirut blood were to be preferred to relics 'from Christ's side' ( $e$ latere), since from a theological point of view no bodily remains of the Saviour could have been left on earth after His resurrection. The question of Christ's relics became an increasingly urgent issue in the history of later medieval Christian theology in the fifteenth century, giving rise to a famous controversy between Franciscans and Dominicans. ${ }^{20}$ Thomas Aquinas, in his Summa theologica, condemned as blasphemous the cult of the holy blood $e$ latere, while assuming that only the Beirut relics and other miraculous effusions from images could be interpreted as true relics of Christ's blood. ${ }^{21}$ In the time of Anastasius the Librarian, veneration of blood relics was a relatively new phenomenon. A famous collection of relics pertaining to Christ's Passion, including one blood ampulla, was housed in the Carolingian abbey church of Reichenau; according to the tenth-century abbey chronicle, the treasure was a donation of Charlemagne, who had received it as a gift from the caliph Harun al-Rashid. ${ }^{22}$

A relic of the Beirut blood and water was translated from Hierapolis to Constantinople in 968 by the Emperor Nicephoros Phocas. ${ }^{23}$ In 975 his successor, John Tzimiskes, obtained the icon in Gabaon. ${ }^{24}$ Pilgrims' stories often mention the blood relic in Constantinople, housed in St Mary of the Pharos in the Imperial Palace, and that the miracle occurred in Berytus: in a great number of twelfth-century texts, the town is referred to as the place of the famous bleeding image. ${ }^{25}$ Veneration of relics from Beirut is documented in western Europe from the late tenth and eleventh centuries onwards, when a number of ampullæ began to be honoured in important towns and pilgrimage centres. One such centre was Oviedo in northern Spain, whose

19 Ibid., col. 585: 'Hæc est vera et vehementer credula ratio de cruore lateris Domini nostri Salvatoris, qui profluxit de sancta imagine ipsius, quæ crucifixa est in Syria, in Beryto civitate. Hic est etiam sanguis ille dominicus, qui apud plerosque repertus esse dicitur. Nec esse aliter æstimandum a vere catholicis, præter id quod scribitur a nobis, quasi ex Carne et Sanguine Christi aliquid possit in mundo inveniri, nisi illud quod in ara altaris per manus sacerdotum quotidie spiritualiter efficitur. Hæc ergo sciens, amantissimi patres et fratres, acceleravi declarare vobis ad ædificationem animarum vestrarum, ad incrementum nostræ fidei, ut et in hoc scire valeatis, quanta sit virtus et pietas Dei et Salvatoris Domini nostri Jesu Christi'.

20) See the text by E. S. Piccolomini, ed. J. Cugnoni, 'Aeneæ Silvii Piccolomini Senensis qui postea fuit Pius II Pont. Max. opera inedita', Atti della Regia Accademia dei Lincei, ser. 3, viii, 1883, pp. 319-652 (615-52). Cf. also M. D. Chenu, 'Sang du Christ', Dictionnaire de la théologie catholique, 15 vols, Paris 1939, xiv, cols 1094-7.

21 Thomas Aquinas, Summa theologica, iii.54.3.

22 Translatio sanguinis domini, in Monumenta Germanice Historica, Scriptores rerum germanicarum (hereafter MGHS), 32 vols, Hanover 1826-, iv, pp. 446-9.
23 Cf. Paris, Bibliothèque Nationale MS grec Coislin 296 , fols $195^{\mathrm{r}}-7^{\mathrm{r}}$ (12th century), and the text reproduced by E. von Dobschütz, Christusbilder. Untersuchungen zur Geschichte der christlichen Legende, Leipzig 1899, p. 218*.

24 See Leo the Deacon's Chronicle, ed. C. B. Hase, Bonn 1828 , pp. 166-8, describing it as an icon depicting the Crucifixion. Cf. C. Mango, The Brazen House. A Study of the Vestibule of the Imperial Palace of Constantinople, Copenhagen 1959, pp. 150-2.

${ }_{25}$ See e.g. Eugesippus's Treatise on the Holy Land (12th century), in $P G$ (as in n. 9), cxxxiii, col. 993; Daniel the Abbot, Life and Pilgrimage (1106), tr. B. De Khitrowo, Itinéraires russes en Orient, Paris 1889, p. 54 (lix); De Situ urbis Ierusalem (1130), ed. S. De Sandoli, Itinera Hierosolymitana crucesignatorum (hereafter IHC), 4 vols, Jerusalem 1978-84, ii, p. 112 (xiv); Rorgo Fretellus de Nazareth, Descriptio de locis sanctis (1137), ed. P. C. Boeren, Rorgo Fretellus de Nazareth et sa description de la Terre Sainte. Histoire et édition du texte, Amsterdam, Oxford and New York 1980, p. 19; Theodoricus, Libellus de locis sanctis (1175), IHC, ii, pp. 382-44 (1) 
Cathedral of San Salvador housed a Beirut ampulla already in the eleventh century; it was included with other precious relics in the so-called 'Arca Santa', a sculpted reliquary commonly said to be the work of the Twelve Apostles, whose cult was promoted by King Alfonso VI of León (1065-1109).$^{26}$ From the twelfth to the fourteenth century Beirut relics were apparently widespread: according to Burcardus of Mount Sion (1283) and other pilgrims, holy ampullæ were common in English and French cathedral treasuries. ${ }^{27}$ After the Fourth Crusade in 1204, one of them, translated from Constantinople by the Doge Enrico Dandolo, was preserved in the church of San Marco in Venice and publicly exhibited every year on 15 August; another was included in the collection of Christ's relics placed by King Louis IX in the Sainte-Chapelle in Paris. ${ }^{28}$

In Tuscany, Beirut cults became deeply rooted. They probably gave rise to the Lucchese veneration of the 'Volto Santo', a wooden crucifix believed at least since the twelfth century to be the work of Nicodemus, the author of the Beirut image. ${ }^{29}$ As scholars have observed, the emergence of the Volto Santo as a venerated image may be the final outcome of a process by which a previous cult of Passion relics, said to be contained in the crucifix, was transformed into a public veneration of the reliquary itself. ${ }^{30}$ A blood ampulla was preserved in the relic collection in Lucca, and, according to the Leobinian version of the Volto Santo legend, another one, found inside the crucifix at the time of its notional arrival in 742, was presented by the bishop of Lucca to the church of Luni. We know that from the twelfth century on this second ampulla was the most precious relic preserved in Sarzana Cathedral. ${ }^{31}$ Although the conceptual boundaries between 'icon blood' and 'Christ's blood' could often be confused, a twelfth-century author, Gervase of Tilbury, had no doubts that both the ampulla in Lucca and the one in Sarzana contained 'blood shed from images'. ${ }^{32}$ They were not, however, the only Beirut relics to be honoured in the region. Two other ampullæ of 'the Saviour's icon' ('ychonie domini') were preserved in Pisa: one in the church of San Pietro in Vinculis, as witnessed by an epigraph dated 1118, and another within the main altar of the town cathedral. ${ }^{33}$ In Siena, a Beirut relic-'Christ's blood shed from an icon (anchona)'-arrived much later, in 1359, when a collection of precious relics bought in Constantinople was sent as a gift to Santa Maria della Scala. ${ }^{34}$

26 D. de Bruyne, 'Le plus ancien catalogue des reliques d'Oviedo', Analecta Bollandiana, xlv, 1927, pp. 93-5.

27 Burcardus of Mount Sion, Descriptio terre sancte (1283), IHC (as in n. 25), iv, p. 134 (iv); Pelrinages [sic] et pardouns de Acre (c. 1280), ibid., p. 114 (xi).

28 On the Venetian relic, see the documents collected by P. de Riant, Exuvice sacre Constantinopolitance, 2 vols, Paris 1877-8, pp. 149-52; on the Beirut relic in Paris and its liturgical cult see ibid., p. 48. Another Beirut blood ampulla was venerated in Bruges: cf. Simone Sigoli, Viaggio al monte Sinai (1384), ed. A. Lanza and M. Troncarelli, Pellegrini scrittori. Viaggiatori toscani del Trecento in Terrasanta, Firenze 1990, pp. 248-9.

29 See P. Luiso, La leggenda del Volto Santo. Storia di un cimelio, Pescia 1928, pp. 36-7, 40; C. Frugoni, 'Una proposta per il Volto Santo', Il Volto Santo. Storia e culto, exhib. cat. (Lucca 1982), ed. C. Baracchini and M. T. Filieri, Lucca 1982, pp. 15-48 (18-19).

$30 \mathrm{H}$. Schwarzmaier, Lucca und das Reich bis zum Ende des XI. Jahrhunderts. Studien zur Sozialstruktur einer Herzogstadt in der Toskana, Tübingen 1972, pp. 335-73.
31 Cf. N. Cocci, Reliquie del sangue a Luni e Lucca: studio storico-agiografico, Rome 1974.

32 Gervasius of Tilbury, Otia imperialia, ed. G. G. Leibnitz, Scriptores rerum Brunsvicensium illustrationi inservientes, antiqui omnes et religionis reformatione priores, Hanover 1707 , pp. 967-8 (iii.24).

33 O. Banti, 'Di alcune iscrizioni del secolo XII su lamine plumbee relative al culto delle reliquie. Note di epigrafia medievale', Quaderni ticinesi di numismatica e an tichità classiche, xix, 1990, pp. 297-319 (302-4); G. Scalia, 'La consacrazione della cattedrale pisana (26 settembre 1118)', Bollettino storico pisano, lxi, 1992, pp. 1-31 (12).

34 I. Gagliardi, 'Le reliquie dell'Ospedale di Santa Maria della Scala (XIV-XV secolo)', L'oro di Siena, exhib. cat. (Siena, Dec. 1996 to Feb. 1997), ed. L. Bellosi, Milan 1996, pp. 49-66 (51). Cf. the 14th-century documents ed. G. Derenzini, 'Le reliquie da Costantinopoli a Siena', ibid., pp. 67-78 $(72,75)$. Although a similar miracle was attributed to another icon of Christ in St Sophia, blood relics were usually identified as pertaining to the Beirut image. 
The legend of the Beirut miracle, in Anastasius the Librarian's version, was widely diffused in medieval Europe. Repeated by Sigebertus of Gembloux, Helinandus and other historians, it became a common moral exemplum, often employed in anti-semitic contexts. It appears in collections of miracle stories from the twelfth to the fourteenth centuries and was often cited by preachers in their sermons. ${ }^{35}$ The most important source for public knowledge of the Beirut story was the liturgy which, at least in some local traditions, commemorated the miracle annually on 9 November. Early references to a feast exclusively devoted to the outraged image occur in some tenth-and eleventh-century Catalan Passionals: a tenth-century manuscript in Gerona records, on 9 November, a 'Passion of the image of the Lord and Saviour which was crucified in the town of Beirut'; and an eleventh-century Vic necrology mentions a 'dies natalis' and a 'celebration' relating to 'the image of our Lord Jesus Christ which was made in the time of Constantine the Younger', noting that this feast was celebrated with great honour throughout the entire world. ${ }^{36}$ The Passio ymaginis office often consisted of the same lections read on 14 September, when the church celebrated the Exaltation of the Cross; and not infrequently, separate formulæ were recited in the Mass. In another eleventh-century text, the Ripoll Sacramentary, we find the following lections:

\section{On 9 November. Passion of Our Lord's image.}

O Almighty and Eternal God, who granted this most renowned day to us, we implore Thee that we may be saved, under Thy protection, from the Enemy's insidious arrows, as we remember in this day Christ Thy son's Passion in His own image. Through the same...

Consecration. We implore Thee $\mathrm{O}$ Lord to sanctify the gifts presented to Thy goodness and, thanks to the Passion of the image of Christ Thy only-begotten Son, drive away the punishments of Gehenna, which we properly deserve because of our sins. He, Who with Thee...

Preface. It is truly worthy ... through Christ... He, Who offered Himself on behalf of sinners and stretched out His arms on the cross for us; He, who repelled the enemy's powers by means of the mystery of the Cross and transfixed all the crimes of mankind in the Cross itself. And so with angels and archangels...

Communion. Nourished with Thy heavenly food and spiritual drink, O Father God, we implore Thy goodness, so that we may merit Thy forgiveness for all our sins, through the Passion of Christ Thy Son's holy image, which we venerate today. Through the same... ${ }^{37}$

The office, reflected also later in other churches (such as Arlés-sur-Tech and Vilabertrán) ${ }^{38}$ clearly stressed the christological meaning of the feast, since it was

35 The Beirut miracle is recorded in the following works: Annales Xantenses, MGHS (as in n. 22), ii, p. 222; Sigebertus of Gembloux, Chronicle, ed. J.-P. Migne, Patrologice cursus completus. Series latina (hereafter PL), Paris 1844-64, clx, col. 145; Helinandus, Chronicle, ibid., cols 829-30 (xlv); Vincent of Beauvais, Speculum historiale, Douai 1624, p. 955 (xxiii.160). On its utilisation as an anti-semitic motif see H. Schreckenberg, Die christlichen Adversus-Judcoos-Texte (11.-13. Jh.), Frankfurt am Main 1991, p. 272; and C. Cruse, 'Stories of Breaking and Taking the Cross: A Possible Context for the Oxford Incident of 1268', Revue d'histoire ecclésiastique, xc, 1995, pp. 396-441. More specifically on its presence in the preachers' sermons, cf. J. Le Goff, 'Les Juifs dans les "exempla" médiévaux: le cas de l'Alphabetum Narrationum', Mélanges Léon Poliakov: le racisme, mythes et science, ed. M. Olender, Brussels 1981, pp. 209-20; and
G. Delcorno, Giordano da Pisa e l'antica predicazione volgare, Florence 1975, pp. 272-3.

36 L. Serdá, 'Los martirologios de la Marca Hispánica en la evolución litúrgica de la misma', Ausa, i, 1952-4, pp. 387-9 (Gerona); J. Gudiol y Cunill, Nocions de arqueologia sagrada catalana, Vich 1902, pp. 318-19 (Vic). See generally J. B. Ferreres, Historia del Misal romano, Barcelona 1929, p. 310. Constantine the Younger may be recognised as the Emperor Constantine VI (780-97); his name was probably introduced because of the Nicæan council, which was held during his reign (787). 37 A. Olivar, Sacramentarium Rivipullense, Madrid and Barcelona 1964, pp. 185-6:

'V idus novembris. Passio Ymaginis domini.

Omnipotens sempiterne deus, qui hunc diem nobis cæleberrimum contulisti, pr[æ]sta qu[æ]sumus, ut sicut hodierna die in immagine sua Christi filii tui passione 
intended as a repetition of Christ's sacrifice and was associated with eschatological and eucharistic themes by analogy with the holy blood and water of the Communion rite. The great symbolic relevance attributed to the ritual is often revealed by eleventh- and twelfth-century liturgical calendars, where the expression Passio ymaginis is substituted by the plain word Salvator. ${ }^{39}$ The custom of dedicating churches and altars to the Saviour's image seems to have been widely diffused in Catalonia: an altar in honour of the Passió de la imatge de Crist was erected, for example, in Vic Cathedral in the thirteenth century. ${ }^{40}$ Moreover, the Beirut miracle constituted one of the main feasts in churches dedicated to the Saviour, and some historians have suggested that wooden crucifixes of the Majestat type (representing Christ alive and clothed in a tunic) should be associated with the commemoration of the Beirut image. ${ }^{+1}$ The Majestats were widely diffused in Catalonia from the eleventh to the thirteenth century and their iconographic features appeared also in Provence, Liguria and Tuscany: the Lucchese Volto Santo is likely to have derived its iconography from analogous Catalan prototypes. ${ }^{42}$ From the beginning of the twelfth century, another Majestat-like wooden crucifix was venerated as the titular image of the church in Bocca di Magra (near Sarzana), whose dedication to the Holy Cross and St Nicodemus was probably connected to the Passio ymaginis. ${ }^{+3}$

On 9 November, although recording the Beirut miracle, the post-Tridentine Roman Martyrology compiled by Baronius emphasises the 'Dedication of the Lateran Basilica' (Dedicatio ecclesia Lateranensis).$^{+4}$ From the eleventh to the thirteenth century most Roman Passionals only recalled the Image Passion, though sometimes the Passio ymaginis was combined with a reference to the Dedicatio. ${ }^{45}$ According to John the Deacon, writing in the eleventh century, this day celebrated the dedication of the Lateran church by Pope Sylvester I, when an image of Christ in the apse was first revealed to the Roman people. ${ }^{46}$ Some authors suspect that this reference to a christological representation was added later and derives from a different tradition concerning a sacred image. ${ }^{47}$ We know from twelfth- and thirteenth-century texts that there was a Roman cult associated with the Beirut miracle. Giraldus Cambrensis records that an image of Christ, placed above a chapel entrance, shed blood when

recolimus, ita ab infestantis inimici iaculis tuo munimine tueamur. Per eundem.

Sacra. Munera tuæ pietati oblata sanctifica $q u[æ]-$ sumus domine, et gehennales cruciatus, quos pro piaculis digne nostris meremur, per unigeniti Christi filii tui immaginis passionem a nobis procul pelle propicius. Qui tecum.

Prefatio. Vere dignum per Christum. Qui se pro peccatoribus tradidit, qui proprias manus extendit in cruce pro nobis, qui adversas potestates per crucis misterium abdicavit, ac tocius humani generis delicta in ipsa cruce transfixit. Et ideo.

Com. Alimonia cælesti potuque spirituali recreati tuam, deus pater, obsecramus pietatem, ut per eandem, quam hodierna die sanctæ immaginis Christi filii tui veneramur passionem, cunctorum a te mereamur consequi veniam delictorum. Per eundem.'

38 V. Leroquais, Les sacramentaires et les missels manuscrits des bibliothèques publiques de France, 2 vols, Paris 1924, i, pp. 330, 333.

39 A. Ebner, Quellen und Forschungen zur Geschichte und Kunstgeschichte des Missale Romanum im Mittelalter. Iter Italicum, Freiburg im Bresgau 1896, pp. 40, 162, 164, 207.

40) E. Junyent, La ciutat de Vic i la seva història, Barcelona 1976 , p. 87.
41 On this point cf. M. Durliat, Christs romans. Roussillon, Cerdagne, Perpignan 1956, pp. 33-4, and 'La signification des Majestés catalanes', Cahiers archéologiques, xxxvii, 1989, pp. 69-95; M. Trens, Les Majestats catalanes, Barcelona 1966, pp. 50-1; R. Bastardes, Las talles romàniques del Sant Crist a Catalunya, Barcelona 1978, pp. 88-90.

42. Such a supposition was first expressed by A. Kingsley Porter, Romanische Plastik in Spanien, 2 vols, Florence and Munich 1928, pp. 9-13.

43 On this crucifix see A. Pertusi and F. Pertusi Pucci, 'Il crocifisso ligneo del Monastero di S. Croce e Nicodemo di Bocca di Magra. Contributo alla storia del Volto Santo di Lucca', Rivista dell'istituto nazionale di archeologia e storia dell'arte, ser. 3, ii, 1979, pp. 31-51.

44 C. Baronius, Martyrologium Romanum, Rome 1630, pp. 552-3.

45 Cf. E. B. Garrison, 'Three Manuscripts for Lucchese Canons of S. Frediano in Rome', this Journal, xxxviii, 1975, pp. 1-52 (19-20); repr. idem, Early Italian Painting. Selected Studies, London 1984, pp. 244-98 (265-6).

ti John the Deacon, Descriptio ecclesice lateranensis, ed. R. Valentini and G. Zucchetti, Codice topografico della città di Roma, 4 vols, Rome 1942, iii, pp. 332-3.

47 P. Jounel, Le culte des saints dans les basiliques du Latran et du Vatican au douxième siècle, Rome 1977, pp. 305-7. 
it was struck with a stone by Roman Jews. From the late twelfth century the image was involved in the ceremonies following the election of the Pope, and the blood relic, included in the 'mensa Domini', was solemnly exhibited by the Pontiff on Maundy Thursdays. ${ }^{48}$ Jacobus de Voragine remembers a Beirut ampulla in the Roman basilica of St Saviour, ${ }^{49}$ and a late thirteenth-century pilgrim, describing the Beirut church of St Saviour-which is said to be the synagogue transformed into a church by the pious bishop of Anastasius's legend-claims that the miraculous icon was later translated to Rome. ${ }^{50}$ The Lectiones Bergenses, a thirteenth-century Norwegian text, declares unequivocally the identity of the Lateran blood with the liquid shed from the Beirut image. In 1214 a holy thorn from Christ's crown was translated to Bergen as a gift of King Philip of France to the Norwegian court. Its arrival, by chance, fell on 9 November, which was interpreted by the Bergen clergy as a divine sign, because the day corresponded in the calendar to the commemoration of the Beirut image, a feast solemnised by many churches and chiefly by the Lateran basilica, where the blood relic had been translated by some converted Jews. According to the version of the legend recorded in the Lectiones Bergenses:

And when it had happened according to the sequence of outrages inflicted on Christ, that they stabbed His side with a lance, immediately blood and water poured out in quantity from the wound. They approached and filled an ampulla with blood, which was later translated by the converted Jews to Rome, into the church of the Holy Saviour; it is preserved still today and a solemn feast is performed on the fifth day before the Ides of November, in memory of our Lord's Passion and in honour of this miracle..$^{11}$

There is good reason to suppose that the commemoration of Beirut image on 9 November was originally chosen as the proper feast of the titular saint of the basilica, i.e. Christ himself or the Salvator. From the second half of the twelfth century onwards, the centrality of the Lateran basilica as 'mother of all churches' prevailed in its dedication anniversary and was stressed in the new 'Ordo officiorum' compiled by Bernhardus, a Lucchese canon. ${ }^{52}$ In the thirteenth and fourteenth centuries the diffusion of Roman liturgical practice resulted in a progressive obliteration of the Beirut image tradition.

The Passio ymaginis office had been, however, widely known in central Italy from at least the eleventh century, as revealed by a great number of Passionals, ranging from Lucca to Perugia and Spoleto. ${ }^{53}$ It was especially observed in monastic contexts, for example in Camaldoli, and constituted the main ritual for monasteries dedicated

48 Cf. S. De Blaauw, 'The Solitary Celebration of the Supreme Pontiff. The Lateran Basilica as the New Temple in the Medieval Liturgy of Maundy Thursday', Omnes circumadstantes. Contributions towards a History of the Role of the People in the Liturgy Presented to Herman Wegman, ed. C. Caspers and M. Schneiders, Kampen 1990, pp. 120-43 (141-2). See also Cencius Camerarius's description of Pope Celestine III's accession ceremony in 1191, ed. C. Baronius, Annales ecclesiastici, 34 vols, Lucca 173856 , xix, cols $626-7$. The same miracle is remembered in the 14th century by the parish priest Stefano's Prologue to the Capitoli della Compagnia della Madonna dell'Impruneta (ed. Accademia della Crusca, Florence 1866, p. 9).

49 Legenda aurea, cxxxvii; ed. Graesse (as in n. 4), p. 609.

50 Filippo Busserio (c. 1260-1340), Liber peregrinationum (1285-91), IHC (as in n. 25), iv, p. 252 (lxv)

51 Lectiones Bergenses, ed. Riant (as in n. 28), ii, pp. 5-6: 'Lectio IX. Cumque ventum esset secundum ordinem opprobriorum Christi, ut latus lancea perforarent, confestim ex latere sanguis et aqua ubertim profluxit. Et suppositam per eos ampullam implevit, quo Rome in ecclesia Sancti Salvatoris a Judeis conversis ad fidem per istud miraculum cum isto sanguine tradita, hodierna die conservatum, et solenne festum in memoriam Dominice passionis, ac in huius miraculi venerationem, quinto Idus Novembris agitur.'

52 Jounel (as in n. 47), p. 307.

53 Twelfth-century Passionals recording the 'Passio ymaginis' or 'ycone' are preserved in Lucca, Biblioteca Capitolare MSS A, fols $142^{\mathrm{v}}-6^{\mathrm{v}}$; F, fols $66^{\mathrm{r}}-9^{\mathrm{v}}$; $\mathrm{P}+$, fols $166^{\mathrm{v}}-8^{\mathrm{v}}$. The story is also included in a 12 th-century Homiliary (ibid., MS 42, fols $114^{\mathrm{v}}-15^{\mathrm{v}}$ ). For Umbrian examples see A. Caleca, Miniature in Umbria. I: La Biblio teca Capitolare di Perugia, Florence 1969, p. 156; B. de Gaiffier, 'Les légendiers de Spolète', Analecta Bollandiana, lxxiv, 1956, pp. 313-48 (339, 347, 348). 
to the Saviour, such as San Salvatore of Mount Amiata. ${ }^{54}$ In an eleventh-century codex now in the Biblioteca Nazionale in Florence (probably from the monastery of SS Flora and Lucilla near Arezzo), the Passio ymaginis lection consists of Anastasius's text and is illustrated by a miniature reproducing a crucified Christ. ${ }^{55}$ A century later, in a Lucchese manuscript known as the P+ Passional, the Salvator, titular of the Beirut feast, is portrayed as a Byzantinising Pantokrator. ${ }^{56}$ Sometimes single episodes from the miracle story are represented: for example, the twelfth-century Stuttgart Passional, a manuscript produced in the north, displays the crucifixion of the icon and the healing of the paralytic man..$^{57}$

The patron saint of Lucca Cathedral was St Martin, but its main rituals related to the cult of the Saviour: the Invention of the Cross on 5 May, the Exaltation of the Cross on 14 September, and the Passio ymaginis on 9 November. On the feast of the Saviour, a large part of the office, consisting of six lections on the Passio ymaginis and three on St Theodore, was performed in front of the Volto Santo (ante crucem) and, as prescribed by the thirteenth-century Ordo officiorum, the liturgical formulæ were the same as used in the feasts of the Holy Cross. ${ }^{58}$ As late as 1753, Giovan Domenico Mansi, an authoritative scholar in liturgical matters, was surprised at the involvement of the Volto Santo in such a rite, while there was apparently no specific reference to the Dedication of the Lateran basilica. ${ }^{59}$

The Sienese office of 9 November was very probably modelled on the Lucchese one; as Mino Marchetti has pointed out, Lucca exerted a great influence on the creation of local liturgies in the twelfth century, when the canons of San Martino and San Frediano were called by Sienese bishops to organise the clergy's common life (as Popes did in the Lateran basilica itself). ${ }^{60}$ As in Lucca, the feast of the Saviour was celebrated in Siena with six lections de icona and three on St Theodore; psalms, prayers, and other formulæ were identical to those recited in the office of the Invention of the Cross on 3 May. ${ }^{61}$ Such a liturgical combination of the feasts related to the Saviour, i.e. the Passio ymaginis, the Invention and the Exaltation of the Cross, sheds light also on the iconographic arrangement of the Siena antependium, since both the scenes illustrating the Beirut miracle and those devoted to the Invention show miraculous events and exemplary deeds-the proper 'hagiographic cycle'pertaining to the Salvator displayed in the central zone. Analogous functions and meanings were probably attributed to a fourteenth-century sculpted retable in Majorca, which was made for the main altar in the hermitage of Sant Salvador, near Felanitx; in fact, as destined for a church dedicated to the Saviour, the image displays

54 Ebner (as in n. 39), pp. 40, 207. K. Berg, Studies in Tuscan Twelfth-Century Illumination, Oslo, Bergen and Tromsö [1969], p. 72 n. 2, was unaware of the meaning attributed to the Passio ymaginis feast, when he rejected a provenance from San Salvatore of Mount Amiata for Florence, Biblioteca Laurenziana MS Amiat. 2 (11thcentury), since 'on 9 November, it is not S. Salvatore that is celebrated, but Imago Domini'.

55 Florence, Biblioteca Nazionale, Fondo nazionale MS II.I. 412 , fol. $119^{\mathrm{v}}$.

56 Cf. E. Nencini, 'Il Passionario P+ della Biblioteca Capitolare di Lucca', Ricerche di storia dell'arte, xlix, 1993, pp. 55-68.

57 A. Bøeckler, Das Stuttgarter Passionale, Augsburg 1923, p. 22, fig. 109. For a post-Tridentine revival of this iconographic motif, cf. a panel by Jacopo Coppi in San Salvatore, Bologna. According to C. Spada, 'Il miracolo del crocifisso di Beirut nella pala di Jacopo Coppi’,
Il carrobbio, xv, 1989, pp. 325-34, it was commissioned by the prior Raffaello Campioni in 1579 as a way of celebrating the ancient dedication of his church to the Saviour; however, the revival of the miracle story was conditioned by its usefulness as an argument against iconoclastic Calvinism.

58 M. Giusti, 'L'ordo officiorum della cattedrale di Lucca', Miscellanea Giovanni Mercati, 6 vols, Vatican City 1946, ii, pp. 523-66 (565).

59 Giovan Domenico Mansi, Diario sacro antico, e moderno delle chiese di Lucca, Lucca 1753, pp. 308-9.

60 M. Marchetti, Liturgia e storia della chiesa di Siena nel XII secolo. I calendari medievali della Chiesa senese, Roccastrada 1991, pp. 23-31, 45-56.

61 J. C. Trombelli, Ordo officiorum Ecclesice Senensis ab Oderico ejusdem Ecclesia canonico anno MCCXIII. compositus, Bologna 1766, pp. 320-1 (Invention), 381 (St Saviour). 
the Crucifixion and Resurrection in its central zone, while the full Beirut miracle is represented on its sides. ${ }^{62}$

It is not so hard to suppose that the Siena antependium could originally have been destined to play a prominent role in the performance of the Saviour's offices. Moreover, as three of the six scenes-those on the left (see Fig. 1)-are devoted to the Beirut miracle, one may suspect that the antependium was specifically made for a church dedicated to the Salvator, as was the abbey of Berardenga, the feast of whose patron fell on 9 November. The inscription on the upper border of the panel specifies that it was made 'in the month of November', ${ }^{63}$ maybe to be unveiled on the Saviour's day.

One can object that all this does not yet constitute a real proof of an origin from the abbey of Berardenga. In Kees van der Ploeg's opinion, Siena cathedral probably housed an altar in the inner choir devoted to the Saviour, so that an antependium displaying scenes from the Beirut and the Invention cycles would have well suited it. ${ }^{6+}$ None the less, an examination of further details seems to support the present thesis. The scene on the lower right (Fig. 7) does not pertain, as we noted, to the Invention story. On the left, it displays a seated figure, probably a dignitary, as seen from his rich clothes; the gesture of his hand reveals that he is giving an order, which a bearded figure is about to carry out. The two other male figures are shown bound together inside an arched building. One is unbearded, suggesting a young man, while his companion is a major prelate, as his mitre reveals: he is addressing a tonsured man on the right, who appears ready to accept the churchman's invitation. This scene aptly illustrates a passage in the Vita of St Alexander, widely diffused in contemporary Passionals. ${ }^{65}$ Alexander, the first pope of this name, was subjected by the comes Aurelianus, an envoy of the Emperor Trajan, to many tortures, together with two companions, the priests Eventius and Theodolus. To persuade them to offer sacrifices to idols, Aurelianus gave orders that Alexander and Eventius should be bound back to back and put in a fiery furnace, while Theodolus was forced to stand nearby and watch his companions' cruel death. However, the incandescent flames were unable to burn their bodies and Alexander asked Theodolus to join them, since they were under God's protection. In the antependium scene, Aurelianus, on the left, is giving his order, Alexander and Eventius are shown bound together inside a furnace (with an opening in the lower part for firewood), and Theodolus, on the right, is represented as a tonsured priest. ${ }^{66}$

62 Cf. A. Duran Sanpere, Los retablos de piedra. II. Los retablos del siglo $X V$, Barcelona 1934, pp. 18-19. For a good colour plate, see V. M. Rosselló Verger, A. Santamaría, F. de B. Moll, and S. Sebastián, Baleares, Madrid 1974 , p. 226 and fig. 97.

63 See above, p. 1.

64 Van der Ploeg (as in n. 6), pp. 75-6.

65 Acta martyrii sanctorum Alexandri, Eventii et Theodoli, in ed. Acta sanctorum Maii, Antwerp 1680, i, pp. 374-5: 'Tunc Aurelianus iussit fortiter incendi furnum, et iussit Alexandrum et Eventium dorsum ad dorsum ligari, et sic præcipitati in furnum candentem. Theodolum vero ante ipsum furnum stare præcepit, ut quasi eorum territus passione ad sacrificandum idolis consentiret. Sanctus vero Alexander clamavit dicens: Frater Theodole, festina venire huc, et age nobiscum, quia ille quartus, qui inter tres pueros Hebreos apparuit nunc hic nobiscum est. Et exiliens in ignem S. Theodolus ingressus est in furnum: et gratias agentes Deo pariter dicebant: Igne nos examinasti Domine, et non est inventa in nobis iniquitas'. Cf. Flodoardus of Reims, De Christi triumphis apud Italiam, PL (as in n. 35), cxxxv, cols 633-40 (iii.2). 66 In the Vita narration, St Eventius is said to be 81 years old, while in the image he is represented as a young man. It is possible that the artist confused Eventius with Theodolus, who is described as young in the Vita but shown as bearded on the panel; however, he probably had no first-hand knowledge of the full story and relied on abbreviated liturgical versions which defined Alexander's two companions merely as 'priests'. An analogous misinterpretation occurs in Petrus de Natalibus's Catalogus sanctorum (Venice 1493, fol. 106 ${ }^{\text {}) . ~}$ See, moreover, the illustration of the same scene in the Stuttgart Passional, whose iconographic disposition is quite similar to that within the Siena antependium (Bœeckler, as in n. 57, fig. 34). 


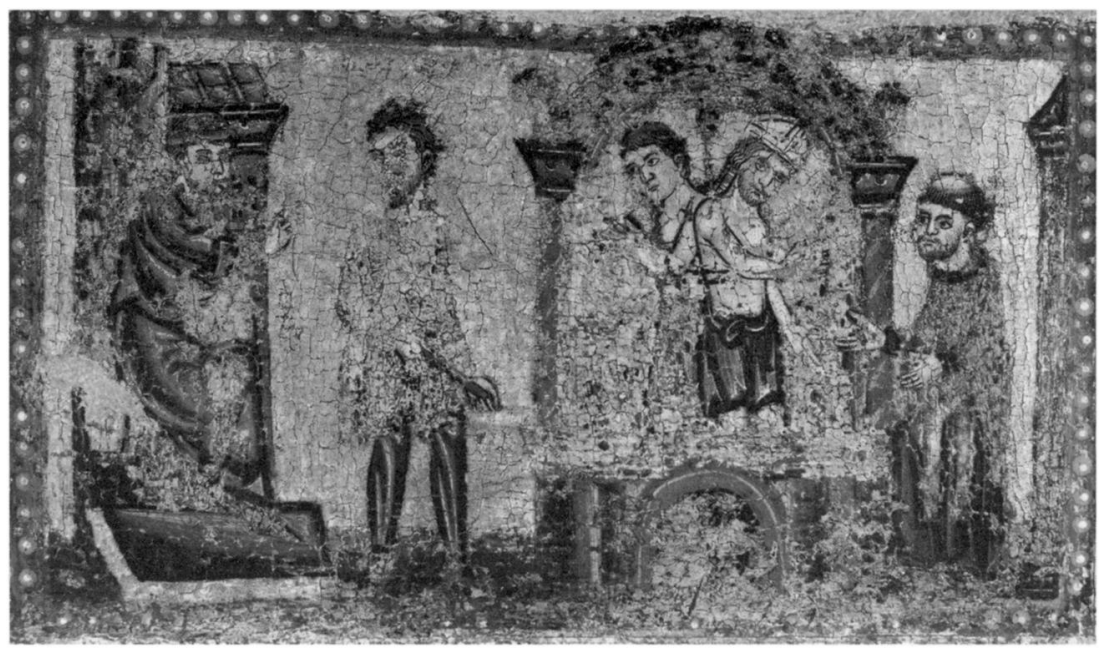

Fig. 7-St Alexander and St Eventius in the Furnace (detail of Fig. 1)

Alexander, as we have noted ${ }^{67}$ was one of the patron saints to which the abbey of Berardenga had been dedicated in 1003, on the occasion of its second foundation by Ranieri and Berardus Berardenghi. Although references to the martyr pope are often absent from eleventh- and twelfth-century documents of the abbey, he was never wholly forgotten. Our antependium, executed in 1215, dates to a period when the Camaldolese monks (who ruled the abbey of San Salvatore) were engaged in a struggle for autonomy with the bishop of Arezzo and the Berardenghi family. ${ }^{68}$ Against this background, it is quite conceivable that the antependium was commissioned as a sort of dedication panel, probably intended for the main altar of the church, on which a reference to the joint patron saint was introduced to stress the ancient traditions of the abbey.

None the less, the criterion which shaped the iconographic programme was more specifically liturgical. To a thirteenth-century observer, the entire composition would have appeared perfectly coherent, since all the iconographic subjects-the central Saviour, the Beirut and Invention cycles and the Alexander scene-made reference to contemporary ritual. In fact, as the Beirut miracle and the Invention story were reciprocally interrelated by their common utilisation in the Saviour's feasts, the inclusion of the St Alexander scene was due both to the church's double dedication and to the martyr pope's commemoration in the liturgical calendar, which fell on 3 May, the same day as the Invention of the Cross by St Helena ${ }^{69}$ In Siena, the deeds of St Helena were honoured with six lections, while another three were assigned to Sts Alexander, Eventius and Theodolus: ${ }^{70}$ a somewhat similar proportion is reflected in the visual organisation of our panel.

In the first quarter of the thirteenth century, as Camaldolese monks asserted the authority of their abbey in the Berardenga area, the execution of the antependium was probably conceived as a symbolic act, stressing the power of the monastic institution. Moreover, its iconographic elements were carefully selected and combined to

68 Cammarosano (as in n. 8), pp. 71-2, 322-3.

69 See Bibliotheca hagiographica latina antiqua et medice atatis, 2 vols, Brussels 1898-9, i, pp. 44-5. 
recall the liturgical rites proper to the abbey of Berardenga, in order to celebrate its local, deep-rooted traditions. This sheds some light on the general function attributed to early antependia in Italy. Conceived as movable objects destined to embellish the front of main altars (the pastiglia decoration of the Berardenga frontal imitates metalwork), they could play an important role in major liturgical feasts. Like the cross exposed on the 'mensa' in Siena Cathedral on 3 May, or the Lucca Volto Santo involved in the Saviour's rites, the Berardenga antependium was employed as a useful counterpart to the liturgical lections describing the Beirut miracle, the Invention story, and the episode from St Alexander's life. Other thirteenth-century frontals and altarpieces showing an analogous arrangement-for example an iconic figure of the Virgin and Child flanked by scenes pertaining to the Nativity cycle, as in the so-called 'Tressa Madonna' ${ }^{71}$-might be destined to illustrate lections proper to specific offices, such as Christmas rites. The main liturgical feasts pertaining to a church were quite often summarised on a single panel-as for example on a frontal now in Spoleto, where a central Virgin and Child is flanked by scenes pertaining to Christ's Passion and to St Martin's life and miracles. ${ }^{72}$ Unlike later iconic vertical panels-for example, Franciscan altarpieces ${ }^{73}$ - where lateral scenes were mostly devoted to celebrating the deeds and miracles of the saint represented in the central zone, the ultimate aim of earlier antependia was rather to play a role in the performance of solemn offices, by providing appropriate pictorial counterparts to liturgical lections.

SCUOLA NORMALE SUPERIORE, PISA

71 Van Os (as in n. 7), p. 12 and fig. 2.

72 Formerly in the abbey church of Santo Stefano near Manciano di Trevi; cf. G. Ceccarelli, Il Museo Diocesano di Spoleto, Spoleto 1993, pp. 27, 37.
73 Cf., on this point, K. Krüger, Der frühe Bildkult des Franziskus in Italien. Gestalt- und Funktionswandel des Altarbildes im 13. und 14. Jahrhundert, Berlin 1992. 